\title{
THE GOOD, THE BAD, AND THE UGLY IN BOSNIAN CINEMA
}

\author{
Lejla Panjeta*
}

\begin{abstract}
The artistic attempt to convey the reality or the author's vision of the reality can be reduced to the simple communication process between the creator of the strategic artistic idea or message aimed at emotions of the recipient. Manipulation with the impact of the art work results in the stereotyped values on the matter presented in the art work. Such impact is vividly evident in the motion pictures. Ever since the beginning of the film exemplary influences of the film on its audience are enormous. It is the inherent feature of film to be convincing, because if it is not, the audience does not believe the interpreted reality or identify with the story, and thus the communication process is not working properly. Why are we watching movies? We do understand that the material before our eyes is not reality, but, nevertheless if it does not follow its own principles of reality that creates within, we do not believe in it. As communication in the art of film is based on the stories, and stories need heroes and enemies, the different parties in the war reality play roles in the film reality. In this reality the perception of what happened in one period of history is represented and interpreted in the movies. This perception depends on authors believes but also political adequacy at the time, place and origin of the finances for the moviemaking. The features of cinematography and storytelling, subjugated to the stereotypes along with the propaganda possibilities and impacts of film contents and contexts in reference to the war and after war reality are the main focuses of this essay.
\end{abstract}

Keywords: Film; Propaganda; Art Reality; Stereotypes; War; Good and Bad; Enemy and Savior

\section{Introduction}

The attempts to convey the reality or the author's vision of the reality can be reduced to the simple communication process between the creator of the strategic artistic idea or message aimed at emotions of the recipient. When looking at the simple Jacobson's (1966) explanation of communication process, one finds that it can be reduced to the simple equation consisting of sender, receiver and the message. The creator or sender of the message puts the information aimed at the receiver's or customer's response. This action produces the message that is received and perceived by the receiver based on his or hers cultural and social background and in doing so produces the reaction of the receiver. This reaction can be considered as immediate feedback to the sender, but also as a delayed outcome of the perceived information resulting in the receiver's beliefs, stands, emotions, behaviour, etc. This simplification of the human communication indicates that it can be of persuasive nature, because in any information that is put into the action by the receiver, 
there is some kind of goal, purpose, hidden agenda or strategy. Whether it's a simple statement that the weather today is bleak or the enchanted advertisement for the new Chevrolet, the sender of the message is sending his or hers own perception of the world towards the receiver and waiting for the response, that can, but does not always have to, qualify as the desired and strategically formed outcome. The impact that the message produces can be anticipated and premeditated by the creator of the communication process. The accuracy in achieving the goals in this persuasive communication is measured by propaganda experts, marketing tools, media and advertisement industry criteria. The sophisticated methods for the manipulation of the receiver's responses are within the realm of propaganda techniques, but we cannot neglect the basic principles of communication that can be of persuasive nature even if it is not conducted by propaganda experts.

The communication principles including sender, receiver and the message are applicable to the art communication and perception of the art work. One of the arts that contain the visual and kinaesthetic qualities that can penetrate psychologically into the receiver's mind is film. Some of the first theories in film at the beginning of the last century were based on psychological research. Psychologists were the first to recognize this fair attraction as something resembling the processes in which the human brain operates, which consists of the insight or replica of non-linear, visual, three-dimension nature of human thoughts.

Psychologist, Hugo Munsterberg, early film theoretic, indicated that film is closer to the mental processes of the individual than any other art (Butler, 2008, p. 14). As in all other human communication processes, here we encounter the Jacobson's principles. The sender or creator is the director of the film, receiver is the audience, and the message is the film itself, consisting of the artistic expression on the given subject it represents or the artistic message. It is evident that the message that is psychologically attuned with our mind has more power on the receiver and can produce greater impact, in co-ordinance with the desired goals of the creator of the film.

Simplifying some phenomenon or notions, for better understanding them and communicating easier in the same context, is what people do in everyday life communication. But, making these contexts become a value is the sure path to creation of the stereotyped versions of reality. According to Nichols (2010) an "ideology describes the lens through which individuals see and understand how they fit into the social world around them" (p. 287). Manipulation with these lenses can form stereotyped values on the matter presented in the art work. The impact it can have is vividly evident in the motion pictures. It can be in a form of bluntly selling the product or an idea (usually political) for the strategic purposes of the sender, but it can also be an indirect propaganda, where the real goal of the sender is not evident (maybe even unconscious for the sender) within the context of the narrative of the film, but can be perceived as general if somewhat elusive

Epiphany: Journal of Transdisciplinary Studies, Vol. 7. No. 2, (2014) (C Faculty of Arts and Social Sciences 
idea (or ideology). Nevertheless, its very existence is possible by the fact that the creator comes from a formed background of ideas and certain cultural context.

\section{The Possibilities of Film Influence in Reality}

Ever since the beginnings of the film, influences of the celluloid narratives on its audience are registered and this new medium, at first considered nothing more than an entertainment tool, showed that the slights of hand can have considerable convincing power. After seeing, what's considered to be the first film, brother Lumière's The Arrival of the Train at La Ciotat in 1895 people jumped out of their seats believing that the train will enter the screening room when approaching in the close up shot to the camera. Broadcasting of the H. G. Well's interpretation of The War of the Worlds in 1983 by Orson Wells, making people believe that the actual aliens are invading earth, caused mass hysteria in USA.

Internal Revenue Service noted the increased tax payments in 1943, after the mass distribution of the cartoon by Walt Disney, in which the famous children's character Donald Duck is portrayed as the conscious citizen and diligent tax payer. The summer film season in 1975 was marked by the box office success of Jaws, the film that is to be taken as one of the first blockbusters. The horror story of the giant shark attacking and killing swimmers and tourists at random in the quiet Amity Island, caused the same devastating effect in the real world of tourism. The summer season was nearly destroyed, because people were afraid to swim in the ocean. The vividly real and palpable fear of the giant aquatic monster was masterly directed by Steven Spielberg, and to this day has gone through so many sequels and different interpretations such as the latest Piranha 3D movie in 2010 (Panjeta, 2006, p. 278).

Brazilian newspaper headlines in December of 1992, covering the story of the murder of Daniela Perez revealed the shocking truth about the psychological process of actors' identification. The partner of this young actress brutally murdered her in real life, after staging and shooting a scene in the soap opera De Corpo e Alma produced by TV Globo. In the said love scene the character played by Daniela Perez states that she does not love her partner anymore. After the murder in real life, the actor surrendered himself claiming that he confused the reality and the fiction he was playing in. The production company was later announced to be the accomplice in this brutal act (Valenti, 1995).

Even in the prehistory of feature movies as artistic expression, but also as an entertainment industry, the extraordinary impact that film has on its users was registered. Becoming aware that there is a possibility to manipulate with these effects the censorship boards that control the content shown in the film are created even at the very early stage of film development. In 1917, the Government of the United States formed the Creel Committee, the authority that was entrusted to make the influence upon the public opinion on the American engagement in the First World War. One of the important media, 
through which the Government infiltrated its messages, was feature movies. On the other continents as well as other historical and social poles, the similar thing happened with the birth of this new form of expression as soon as its massive influence as the new form of mass media with unique audio-visual language was discovered.

It is no secret that Goebbels and Stalin were sitting in the editing rooms along with the filmmakers whose work is today considered anthological and films classical. Leni von Riefenstahl work in propaganda documentaries and the father of the editing techniques, Sergei Eisenstein were closely connected to the men in power (Gregor, Patalas, 1998, p. 103 and Bergan, 2006, p. 291). At the Oscar Winner Award for 2013 there were the greetings from the White House for a film about USA-Iranian relations, praising America's freedom of speech, democracy and individualism, opposed to social and cultural values of Iran, and considering the current state of diplomatic and political relations between Iran and the United States, shows that the seemingly liberally organized film productions have relationships with their superior political and state apparatus. The film is now as it was since its beginnings used intentionally or unintentionally for propaganda purposes.

One of the inherent features of film, the psychological phenomenon of identification, can also be used as an asset in spreading premeditative messages. If considered from the semiotics point of view, the indexical quality of film image gives the fictional worlds the quality of real. The relationship between the image and what it represents is faithful and in the realm of reality, because of the mimetic embodiment characteristic for all the performing arts. The accuracy of the image with its referent in the real world is the characteristic of film language and kinaesthetic storytelling. The identification with this world for the recipients of the film as the message itself is just the result of this semiotic quality.

The above stated impacts that movies can have on the spectatorship are not always premeditated. These are rampant evidences and extreme examples of the influence the film can have and the consequences of the impact it conveys through the idea of the author (creator of the communication process) and the artistic message. It is an inherent feature of film to be convincing, because if it is not, the audience does not believe the interpreted reality or identify with the story, and thus the communication process is not working properly. Truthfulness and verisimilitude are the immanent features of narrative in film language. Riccioto Canudo's manifest The Birth of the Sixth Art from 1911 for the first time argued and proclaimed cinema as the new art and the synthesis of the five ancient arts: architecture, sculpture, painting, music, and poetry (Stojanović, 1978, pp. 51-53). Plato's mimetic art quality was immediately recognized among early film theorists.

Realism as the main style was implemented immediately in this new art. The main feature of realism is to present the world as the real one, in which all the narrative 
elements (plot, situation, characters, conflicts, locations, etc.) stand on their own within the organized structure of the story conducted by that own world's rules. According to Nichols (2010) "realism as a self-effacing form of storytelling draws on the general tendency in much art to hide the process of its own making in favour of the impression that the world it represents exists on its own, autonomously" (p. 177).

\section{Film Reality and Interpretation}

Even latter stylistic features in film, such as modernism and postmodernism, are relating to one simple quality of film: it has to be real to be convincing. The pioneer in documentary Dziga Vertov experimented with the leftovers film stock in the editing room, making the new document of the already documented reality on the film reel. For him, the camera and editing are equal in the process of filmmaking and by reformulation of the reality; a new, more perfect reality is born, seen through the cinematic, as well as human lenses of the creator of the film. His famous statement: "Life caught unawares" refers to the ability of film to be perfect as opposed to the imperfections of human eyesight (Cook, 2007, pp. 203-207). This cinema-eye perfection enables the creator to reinvent the perfect reality (or a new one) according to his own ideas and the messages that he wants the audience to be focused on. Nevertheless, everything in this process of cutting and editing reality depends on the point of view of the author. Whether it's the fantasy world or the documentary, both of these genres are in the domain of mimetic and realistic qualities. The audience easily identifies with the reality on the screen. This reality can transfer the real reality, as the photograph does. The birth of cinema is characterized by this kind of mimesis.

Documentation of the train arrival to the station by brothers Lumière is copy pasting the real life. On the other hand A Trip to the Moon from 1902 makes its own reality. This first fantasy film, by George Méliès, draws the viewers into the fantasy travel to the space, but nonetheless very much real within its own made up narrative elements rules. This discrepancy between fantasy and realism is evident at the beginning of film, but also accurate and applicable today within the complex genre system of film storytelling. Both opposing styles have possibilities to be suggestive and persuasive, because both are real and we believe in them.

The story of President Abraham Lincoln can be told in a realistic manner as was done by Steven Spielberg in an Oscar awarded film Lincoln from 2012. In the same year Abraham Lincoln: Vampire Hunter a fantasy horror vampire movie was released, directed by Timur Bekmambetov and based on the novel by Seth Grahame-Smith. Both are indexical presentations of reality and mimetically interpret the made-up world of fiction based on the true events in history. One is a drama, and the other a vampire action. In both films we entrust our belief that the reality represented on screen is worth trusting and following. No other art has this trust issue with its recipients. For literature one does not need to trust, but imagine. When reading fiction or poetry imagination is the most important factor in the 
communication process. For paintings and fine art, aesthetic components of admiration, not trust in the given reality, is what is important. For music, emotions and catharsis, but not trust, are the most inherent features of the artist - consumer process.

Through the specific performing, visual, audio, kinaesthetic, light, framing elements, this film language enables the indexing of one reality chosen by the creator of the media content that is the fixed image of the real; space taken in one moment of time with the narrative or plot filling the framed reality whose important feature is identification. Persuasive quality of this media can be found in the basic elements of its language, or code in which the massage is transferred to the recipient. When we think that someone is a lousy actor, or that the film story is unconvincing, it is the viewers' trust that was betrayed in the communication with the filmic interpretation of the given reality.

Film is, therefore, mimetic interpretation of the creator's vision and presentation of some given reality. The story of Snow White is worldwide spread and known, and it can be interpreted like Disney's 1937 animation or 2012 gothic horror version of Snow White and the Huntsmen. But, in both versions the good guys and the bad guys are the same: wicked evil stepmother is the antagonist (the bad guy), and the beautiful, innocent Snow White is the protagonist (the good guy). Everything else can be interpreted according to the author's vision. War is similar to fairy tales. It is a story of two different sides; good and bad. How to portray the war in the fiction, and stay true to the reality of good and bad, as well as the victims and aggressors point of view? There be both in the real life, but is there room for both interpretations on one screen? If so, how is then possible to transfer such reality on screen without taking sides and producing further conflict. Is it possible for film to not use the above described persuasive techniques (intentionally or not) and stay true to reality? Which or whose interpretation of reality?

What if or when the reality is no longer to be trusted? What happens when the mainstream, official government or even oral history has lost its credibility? The media infiltrated messages of hate, that produced the conflict in the first place, are information covered in lies, aimed at the mass audience with the goal of making devastating war to be the final outcome of this propaganda communication. This communication coded in film language of close-up persuasiveness, depends on the audio-visual language of news, first invented on the silver screen as the film language. It uses identification as the tool for persuasive communication outcomes. If film can be used for purposes of creating bad in the real world, can it be also a tool for happy ending in reality? Bearing in mind the film persuasiveness; can film depict or reinvent the reality, for the benefits of future reconciliation of the sides in conflict?

\section{The Origins of Bosnian Cinematic Sentiment}

The cinema crisis today can be argued in two different opposing discourses. One is

Epiphany: Journal of Transdisciplinary Studies, Vol. 7. No. 2, (2014) (C Faculty of Arts and Social Sciences 
mostly philosophical and the other of an entertainment origins. European film today is engaged elite cinema questioning the ordinary middle class people and styles of lives. It is somewhat a moral debating of present time and social connotations. Hollywood movies, on the other hand, are based on the traditional realistic and/or postmodern narratives wrapped in the often persuasive roller coaster spectacle of visual enchantment. Bosnian films, being of European origin, tend to incline to the more philosophical rather than entertainment styles. Although, one can argue that the majority of Bosnian after war films has humorous (black-humour) and absurdity note on the subject of national conflict and war. The absurdity of Bosnian war is very explicitly given in the last shoot of Oscar awarded feature film No Man's Land from 2001. A man is left on the ticking bomb by everyone (soldiers in conflict, journalists, European Community, United Nations official, etc.), after what's been rifling and an oral squabble of why and how the war started.

For Bosnia, the filmmakers stand as her best representatives, having gained international recognition in the film festivals around the globe and international audience interest.

According to Goulding (2002)

before the breakup of Yugoslavia, Sarajevo, the capital of BosniaHerzegovina, was a small but vital and lively centre of film production and film culture. In the late 1950s, the Sarajevo group of documentary filmmakers associated with Bosna film established a well-deserved domestic and international reputation for stylistic inventiveness and political boldness (p. 228).

The Bosnian cinema is not to be considered outside of Yugoslavian cinema, because its growth was directly related to the other republics in Ex-Yugoslavia and the same cinematic identity of realism is inherent for the films made from 1960s to the 1990s. Modern Bosnian films are not selling illusions but reality. Every since the beginnings of Bosnian film in the Yugoslavian Cinema in the 1960-s, the narratives represented in films depicted plots and life problems of the ordinary people lives and middle classes. As Goulding (2002) has stated "as in past periods, feature films (as well as short films, documentary films, and animated films) continue to be made that offer stylistically varied, non-genre-driven narratives and critical visions of an often tragic past and a complex, unpredictable, and volatile present" (p. 232).

Bosnian bleak reality is often so represented in the Yugoslavian cinema. The tradition of tragic stories in postmodern times, where tragedy is everyday life Bosnian war and after war experience continues in the modern Bosnian film. Having deficient public and government support for the movie production, Bosnian films (made by Bosnian authors and taking place in Bosnia) are often coproduced by European funds and state funds from the neighbouring countries Croatia, Serbia and Slovenia. Having the multicultural, 
multi religious filmmakers, authors, producers and film crews working together on the film reality of war and after war reality, what would be the propaganda mechanisms for imposing the author's version of the war? Where to look for the suggested ideology and opinions of the author behind the film reality?

Representation of the reality that film is offering consists of the plot (usually conflict) based on the actions and motivations of the characters. The cultural background of the character can be presented (manipulated) in the behaviour, the lines and actions, and costume. The point of view of the camera (position of the camera), framing and editing within the constrictions of the genre or pure author style is imposing a certain idea on the reality represented in the movie. Looking at these parameters is it possible to determine how is the Bosnian reality propagated in the film?

\section{Purgatory in Bosnian Film Realism}

Film narrative originates from performing arts and literature. Drama and action between the characters is the essential narrative tool, and it cannot exist without a conflict. No one wants to see happy people being happy. A good story consists of the plot that indicates a conflict between the good guy and the bad guy. Using appropriate professional terminology, the story is based on the opposing interests of the protagonist and the antagonist. Propaganda of protagonist is the anti propaganda of the antagonist. The protagonist's existence is conditioned by the antagonist. In other words, if there is no one to fight with, and nothing to fight for, the protagonist cannot exist. Here lies the argument for close connection between propaganda and film; in order to have a protagonist, a bad guy must be created. Bad guy is the enemy, a good guy the saviour or the victim. Basically, and taken the dramaturgy in a very simplified manner, stories are the conflict between the good and the bad. As is the war. Or is it? Is there something more Ugly behind it?

For most stories in the official history the bad guy is stereotypically and ideologically detected and commonly accepted. In films stereotypes have to be created because it has to be clear who the good guy is. The film reality succumbs to the reality of good and bad. The battle between good and evil is an essential narrative for films. After the devastating war in Bosnia from 1992 to 1995, no winner is official proclaimed. The Dayton Accord signed in December 1995 stopped the killings and that's how the massacres in the centre of Europe in the $20^{\text {th }}$ century were ended. No winner. The International Court of Justice in The Hague in 2007 delivered the decision on Genocide (not ethnic cleansing) committed in Srebrenica. Two entities: Serbian and Bosnian-Croat were created, as those were major two the sides in the conflict. Bosnian history now has the story with no winner that will always be subjected to the future interests of power. In this regard Goulding (2002) has stated that "while many cities may wish to boast of their multicultural tolerance, Sarajevo has lived it for several centuries. It is a tolerance that embraces and celebrates Moslem, Jewish and Orthodox religions and customs - a tolerance that embraces Bosnian Serbs,

Epiphany: Journal of Transdisciplinary Studies, Vol. 7. No. 2, (2014) (C Faculty of Arts and Social Sciences 
Croats, Muslims, and other ethnic groups and nationalities“(p. 231). It is evident that so many Bosnian films are keeping and propagating this multiculturalism quality. Characters are of different national and religious backgrounds and not necessarily the bad guy is always the aggressor or soldier.

Whether it is Nafaka, that humorously depicts war and its aftermath, or Turneja, a Serbian movie that describes the beginning of the war from the point of view of the theatre group from Belgrade that happen to be in the wrong place at the wrong time, or Bosnian films, Djeca, Ostavljeni, Grbavica, stories about the post-war perspective of the younger generation, whose life is effected extremely by the past. All of these movies are not openly propagating either side in conflict, but rather sophisticated ideological opinions and views are subtly given through the characters' behaviours and actions. The bad guys are stated clearly, but not insisted upon. The memory of enemies and victims is changeable, as perceived in Krugovi, but one adamant position of authors of these films stands: war was unnecessary, there were no winners, and it was all for nothing.

Almost all the domestic film production in the ex-Yugoslav region inclines subtly to the ideological views of the country of origin. But, all the post-war films are coherent in one idea; the war was stupid and the consequences devastating. Traditionally depicting a Joe - the neighbour, and his life as the absurdity in tragedy with wider connotation on the present society, the contemporary Bosnian films are not bluntly propagating either side in conflict. Subtle offensive characterizations in lines or action of the antagonist are noticeable, but not adamantly claiming the rights of the winner and hero. Twenty years after the war one would expect to find at least one feature movie in the James Bond style, or at least following the Yugoslav cinema tradition of partisan action films. But, of all the films made, every one of them is related to the war and after war experience; and none of them is made in the style of action-hero-savour-of-the-day-propaganda. Sergei Lukyanenko in his bestselling gothic novel Night Watch stated: "Once you start understanding the enemy, you lost the war" (2008, p. 132)

The Bosnian understanding of what the war was like for a common citizen (ordinary film character) is best explained in the tragically ending comedy Gori vatra from 2003. Bosnian Muslim Hamdo and Bosnian Serb Stanko are having a drink and discussing the war and who started it referring to it as a "screw up." Raising their voices in the conclusion that the problems in the whole story were the outsiders who came to save "me and you." The conversation ends bleakly stating that the separation to each of its own ethnical groups was unnecessary. The film is not negating the fact that the Serbs were the bad guys in the war, but also portrays some Bosnian Muslims in the post-war period as corruptive and morally devastated.

Almost grotesquely comic are the Muslim, Serbian, Croatian and Albanian

Epiphany: Journal of Transdisciplinary Studies, Vol. 7. No. 2, (2014) (C Faculty of Arts and Social Sciences 
characters in Parada from 2011. Ex war heroes (each on their own side) that are united as bodyguards of the gay pride procession in Belgrade against the almost neo fascist chauvinist youth. As much as the earlier work of Srdjan Dragojević can be considered ideological and provocative, this film is mocking the war conflict and even though the stereotypical characters are offensive cultural representation, the film ends in the bitter sentiment of the tragedy and absurdity of violence. The bad guys are defined, but do not bare the necessary mask of religion, ethnicity or nationality. Opposing to the bad guys in reality but also heroes of the film (war criminals) these violent filled with hatred antagonists are the really bad ones - ugly ones. This concept of someone outside being the Ugly one (international community or fate itself) is evident in the 2010 snuff Serbian film Srpski film. If the content of this film is reviewed as the metaphorical subtext, the context is connotative and applicable to the war and break off the Yugoslavia. Again, the man shooting, directing and producing the slaughter (gaining money on it) in the last scene of the movie is the Ugly one. It is an evil even greater than the bad for which Bosnians, Serbs and Muslims were capable of during the real war. No real propaganda on bad guys and heroes is given in these films. In this regard Goulding (2002) stated that

the nearly four years of war in Bosnia-Herzegovina, and the brutal fortysix-month siege on its capital, Sarajevo, had a devastating impact on all aspects of life and culture. Enduring the longest siege of a major city in modern history, Sarajevo was mercilessly subjected to months of terrifying shelling and sniping... What remained intact, however, was a small group of talented Sarajevo filmmakers who chose to remain in their city and to shoot back - not with bullets, but with expertly aimed cameras trained with unerring accuracy on the profoundly important human stories that were unfolding daily, and demanding to be told" (p. 229).

Who was telling these stories? The ones who were at the same time witnessing the horrors of war and devastation of their city; and not only documenting the reality on film, but putting it into the fictional reality in movies.

Masterly film essay from 2000, by Srdjan Vuletić, the short film Hop, Skip, Jump, as well as the brilliant sequence shot in Ahmed Imamović's 10 minuta, point out that the bad guy behind the line is killing innocent civilians, children and women, but the idea behind it is not to propagate emotions of hatred, but of abhorrent disgust over what people are capable of and question the limits of humanity in general.

These films are capturing the Vertov's idea on cinematic perfection of the eye, accurately making a new reality as an interpretation of the real horror of war. Who started or won the war is present but diminished, because the Ugly truth has shown its real face, which is beyond the black and white fiction reality and is dragging the good guys into the grey monotony of Dante's purgatory. This is how most of the modern Bosnian cinema could

Epiphany: Journal of Transdisciplinary Studies, Vol. 7. No. 2, (2014) (C Faculty of Arts and Social Sciences 
be described. It is a Purgatory for ordinary people that are heroically trying to overcome the tragedy that descended on them. The bulk of the Jean-Luc Godard's Notre Musique from 2004 takes place in the after war Bosnia, and is referred to as Dante's Purgatory. The film transcends the elusive idea about the collective conscience of humanity and hollowness of secularism as well as religious empathy that requires the good guy to be the victim for the system of our reality to be stable. Collectiveness represented and interpreted by the creator of the film through the individual strives, sacrifice, suffering, devastation, destruction, violence is not stereotyped, it's just unimaginable, as is something that could not happen even in the movies.

Savršeni krug, the first after war Bosnian film is a metaphor for the siege of Sarajevo in reality, but also the connotation of resistance and refusal to submit in the face of violence and surrender by dying. The idea of totally experiencing the opposing religions and multi culture by an individual becomes collective in the film reality. Shot on the real locations, devastated by the shelling; the set designs are ideological, because they become the witness of the certain historical reality. Thus, Nichols (2010) stated that „form, ideology, and politicizing effects enjoy a shifting, unstable relationship that is best understood when located in relation to a given historical moment and particular audience"(p. 324).

The truth caught in Savršeni krug is evident to the survivors. In the same way the fake set design of the fighting scene background in which the glass windows are intact can be easily detected in the 2011 In the Land of Blood and Honey by someone who has witnessed the siege of the European city at the end of $20^{\text {th }}$ century. The indexical quality is an issue here, because it does not correspond with the referent, but also does not make its own references in the fictional world, making it believable. The film loses the viewers trust (especially survivors' attention) not just because the images aren't transcending the right message. The story is purely conceived as the romance between the victim of the rape and the rapist. It is rumoured that the film is inspired by the true story. The reality behind it is not questionable. The film reality is not holding well the strings and stretches of the narrative, performing and editing.

The reality in the Italian movie from 2012, Venuto al Mondo, that takes place in Sarajevo before, during and after the war, is much more convincing and true to the original referent in reality, even if it is pure fabricated image of reality that surpasses the indexical quality and passes beyond to the metaphorical symbols. Even if metaphorical and artistic, the reality is believable and the emotional impact gigantic in a still shoot of the two windows that are shattered and lighting subdued to the grey gloomy purgatorial colours of the war, during which the song by Nirvana in interrupted by the loud explosion, after which the window view becomes the war sight. One of the best foreign movies about the war that are indexical and symbolic at the same time to the referencing reality of war

Epiphany: Journal of Transdisciplinary Studies, Vol. 7. No. 2, (2014) (C Faculty of Arts and Social Sciences 
is Shoot through the Heart from 1998. The twisted, almost surreal world of city during the siege and subtle explanatory features of the everyday life, are of the utmost importance for any study of the war. Good guys and bad guys are defined and their motives explained. As well as in Welcome to Sarajevo, by Michael Winterbottom from 1997, the set design in both movies is real and locations for shooting were devastated in reality, so this visual feature has noticeable impact.

Foreign movies are in need to determine who started the war, whereas domestic, including the Serbian films, are harsher and more realistic in depicting the horrors of war but not focusing so much on the bad guy. They also do not openly state that everybody is equally to blame. The general idea can be drawn as a conclusion that the war is stupid, and we did not need it. As the good story needs the dichotomy of good and evil, foreign understanding of Bosnian conflict has to be simplified and stereotyped. It is often given as a justification of the political silence at first and then the humanitarian or military intervention. The conflict between Hamdo and Stanko (the Bosnian pronunciation of the names sounds similar), both Caucasian, similarly dressed, visually from the shared social status, and judging by the eloquently delivered lines having the same background education, is an incomprehensible phenomenon to be solved unless one of them is on the side of evil completely. The complex social, cultural, religious, historical web of relationships that these imaginary guys have has been media manipulated to the conflict with desolate consequences for both sides.

That's why The Hunting party, directed by Richard Shepard in 2007, tells the story of the catching of the bad guy, the war criminal Radovan Karadzić. It is very clear who the good guys are. Although filled with stereotyped judgmental images, the impression of justification, remorse, and pay off for the actions international community and the USA were taking (not taking) concerning the war in Bosnia is the major idea behind the film. Opening scene shows the arrival of the plane to Sarajevo International Airport along with the collage of images associated with Bosnian. The background music is of oriental origin, as has nothing in common with the Bosnian musical heritage. The shoot of an old guy in the Old Town of Sarajevo that was constructed during the Ottoman rule in middle ages, shows the fez on his had that has not been worn in real life for a century. Incidentally that costume is also of the Ottoman origin, not Bosnian. The comparable referent this stereotyped image, would be if one expected a cowboy to greet him or her upon the arrival at the J.F. Kennedy Airport in USA. The final title card in the film justifies the international involvement in the conflict, pointing out the Bad guy:

In theory, the official hunt for war criminals, in Bosnia continues to this day. However, the two most wanted men - Radovan Karadzić and Ratko Mladic - continue to elude the US, the United Nations, the European Union, NATO, The Hague and all in the civilized world who claim to be looking for them. In the ten years, that Radovan Karadzic has been on the run, he has 
published two books and one play. Perhaps, if the International Community opened summer stock theatre...

One year later the war criminal was caught. Still, the Bosnian and foreign cinema on matters presented about the war has not been able to catch the Ugly truth on how and why the conflict happened in the first place, and whether it is going to happen again. The brilliant Croatian film directed by Arsen Ostojić, Halimin put from 2012, taking place in Bosnia and based on the true events, covers the shocking story of an adopted child raised by the Muslim family and killed accidentally by the biological father in Serbian Army. Horror of the absurdity of life, powers beyond our reach, manipulation with the masses, the birth mark of an enemy for other religions and cultural groups, is what the real Ugly face looks like in Bosnian reality and cinema.

\section{Imposing You with the Conclusions...}

Film can be a persuasion tool, but is also a work of art and a testimony of the social context that it interprets. This interpretation might be intentionally stereotyped or unintentionally, ideologically driven point of view of the creator of the film idea and messages.

Subtle infiltration of ideas and reformulation of truth in the creation of the fictional truth is subjected to propaganda manoeuvres, that can have great impact on the audiences' ability to identify with the good and the bad represented in the film. The general impression of the Bosnian cinema after the war, given the argument that no James Bond feature was made, and the grey reality of war and after war purgatory places the characters as either antiheros or victims, leaves the bitter taste of need to blame someone. If there is no explicit hero, is there an enemy? Is it possible that the Bosnian films, with all the propaganda impact film can manipulate with, are not capable of conducting a major propaganda effect after the Bosnian conflict? Was the conflict devastating and absurd to the point of numbness on the international scale of humanity? The Bosnian cinema becomes the memory of the culture in time and absurdity of conflict. The real bad guy is not propagated openly and the hatred is not heated up by the propaganda techniques that film could use to this purpose. For transgressing the etiquette of the bad guy to the metaphorically powerful and beyond comprehension Ugly one, maybe this cinema can have a reconciliatory outcome and warning effect for the future generations.

Analysing the Jacobson's communication process in the limelight of humanly inherent persuasiveness, every film with its powerful audio-visual identification feature can be considered propaganda. Any film critic or analysis as well. The film referencing done in this essay can be differently understood and interpreted. It is the author's wish to have it enlighten the new insights and arguments for further debate or persuasion. 


\section{References}

Bergan, Ronald. 2006. Film. Eyewitness Companions. London, New York: Dorling Kindersley Ltd..

Butler, Andrew M. 2008. Film Studies. The Pocket Essential. Harpenden, London, UK: Pocket Essentials.

Cook, David. 2007. Istorija filma I, II, III. (1981, 1990, 1981) (A History of Narrative Film). WW.Norton for Company Inc. Beograd: Clio.

Goulding, Daniel J. 2002. Liberated Cinema: The Yugoslav Experience, 1945-2001. 2 ed. Bloomington \& Indianapolis: Indiana University Press.

Gregor, Ulrich, and Enno Patalas. 1977. Istorija Filma. 1960. Gescihte des Films. Munchen, Gutersloch, Wien: Verlagsgruppe Bertelsmann GmbH C. Bertelsmann Verlag. Beograd: Institut za film.

Jakobson, Roman. 1966. Lingvistika i poetika. Beograd: Nolit.

Lukyanenko, Sergei. 2008. Noćna Straža. 1998, Noćnoi dozor. Trans. Nikolić, Nataša. Noćna Straža. Vol. 1. 4 vols. Beograd: Alinari.

Nichols, Bill. 2010. Engaging Cinema: An Introduction to Film Studies. New York, London: W.W. Norton \& Company Inc.

Panjeta, Lejla. 2006. Potreba za smislom: Mit, manipulacija i film. Sarajevo: Svjetlost.

Stojanović, Dušan. 1978. Teorija filma. Beograd: Nolit.

\section{Films}

10 minuta (10 Minutes), 2002, Ahmed Imamović

Abraham Lincoln: Vampire Hunter, 2012, Timur Bekmambetov

A Trip to the Moon, 1902, George Méliès

Djeca, 2012, Aida Begić

De Corpo e Alma, 1992, TV Globo

Gori vatra (Fuse), 2003, Pjer Žalica

Grbavica (Esma's Secret - Grbavica), 2006, Jasmila Žbanić

Halimin put (Halima's Path), 2012, Arsen Ostojić

In the Land of Blood and Honey, 2011, Angelina Jolie

Jaws, 1975, Steven Spielberg

Krugovi (Circles), 2013, Srdjan Golubović

Lincoln, 2012, Steven Spielberg

Nafaka, 2006, Jasmin Duraković

No Man's Land, 2001, Danis Tanović

Notre Musique, 2004, Jean-Luc Godard

Ostavljeni (The Abandoned), 2010, Adis Bakrač

Parada (The Parade), 2011, Srdjan Dragojević

Savršeni krug (The Perfect Circle), 1997, Ademir Kenović

Shot through the Heart, 1998, David Attwood

Snow White and the Huntsmen, 2012, Rupert Sannders

Snow White and the Seven Dwarfs, 1937, William Cottrell, David Hand, Wilfred Jackson, Larry Morey, Perce Pearce, Ben Sharpsteen

Srpski film (A Serbian Film), 2010, Srdjan Spasojević

Epiphany: Journal of Transdisciplinary Studies, Vol. 7. No. 2, (2014) (C) Faculty of Arts and Social Sciences 
Telenovelas: BBC, 1995, Alexandre Valenti

The Hunting Party, 2007, Richard Shepard

The War of the Worlds, 1983, Orson Wells, Radio drama

Turneja (The Tour), 2008, Goran Marković

Venuto al Mondo (Twice Born), 2012, Sergio Castellitto

Welcome to Sarajevo, 1997, Michael Winterbottom

The Arrival of the Train at La Ciotat, 1985, Auguste Lumiere and Louis Lumiere. 